\title{
The Eruption of Timor in 1638: 350 years of plagiarism, embellishments and misunderstandings
}

\author{
Russell Blong* \\ Risk Frontiers, 8/33 Chandos St., St Leonards, NSW 2065, Australia.
}

\begin{abstract}
In 1665 Athanasius Kircher included a short paragraph in his Mundus Subterraneus about a flamy spire and the collapse and disappearance of a high mountain following a 'horrible earthquake' on Timor in 1638. Although Timor has been known to have no volcanoes for at least the last century, Kircher's story has been repeated for 350 years, generally without acknowledgement, and often with the addition of embellishments and/or errors. This study traces the various accounts and the ways in which the story has morphed, particularly in the early $19^{\text {th }}$ century, when the emphasis in Kircher's story changes from a 'flamy spire', a 'horrible earthquake', and the collapse of the volcano into a continuing Stromboli-like eruption with no mention of an earthquake. Strangely, the fiction that the flamy spire could be seen from a distance of 300 miles is maintained and other embellishments added up to the present day.
\end{abstract}

Keywords: Timor; Volcanic eruption; Earthquake; Kircher; History; Archives

\section{InTRODUCTION}

In the early 1970s I came across the Phil Trans Royal Society paper on "The Dust Veil Index" by the renowned English meteorologist H. H. Lamb [Lamb 1970]. I noticed that an eruption on Timor was recorded for the year 1638. I had been to Timor-Leste (at that time Portuguese Timor) in 1972 and was fairly certain that there were no volcanoes on the island of Timor (c.f., Neumann van Padang [1951] and van Bemmelen [1949]*). Lamb gave as his reference the "List of principal ascertained volcanic eruptions from 1500 to 1886 " in the Royal Society report of 1888 on the 1883 eruption of Krakatoa (now Krakatau) [Symons et al. 1888]. I wrote to him and he graciously confirmed that he knew no more than was recorded in the 1888 Royal Society report; that is, there was no reference to an earlier source. Thus began a search that has intrigued me, on and off, for nearly fifty years.

Within a year or two I had found George Adams' 1912 paper in the Philippines Journal of Science. Adams, a professor of geology in Tientsin, China, asserted that there were no active or recently active volcanoes on Timor and traced the source of the information about the 1638 eruption, via various intermediaries, back to a 1671 publication by Thomae Ittig, a Jesuit priest [Adams 1912; Ittig 1671]. Later, I found what appears to be the initial published source, Mundus Subterraneus by Anthanasius Kircher, a prolific Jesuit author and

\footnotetext{
*Corresponding author: rblong43@gmail.com

${ }^{*}$ Interestingly, none of the great Dutch volcanologists and geologists working in Indonesia (R. D. M. Verbeek, H. A. Brouwer, Reinout Willem van Bemmelen, Herman Th. Verstappen, and M. Neumann van Padang among others) from the 1880s to the early 1950 s appear to even mention the eruption of Timor.
}

polymath. Mundus Subterraneus was published first in Latin in 1665, and then a partial translation appeared in English in 1669 as:

The Volcano's: OR, Burning and Firevomiting Mountains, Famous in the world: With their Remarkables. Collected for the moft part out of KIRCHER's Subterraneous World; And expof'd to more general view in Englifh, upon the Relation of the late Wonderful and Prodigious Eruptions of Aetna. Thereby to occafion greater admirations of the Wonders of Nature (and of the God of Nature) in the mighty Element of Fire.

Page 13 in the 1669 version (identical in this section to the 1665 Latin version), states:

The Mountain Pico in the Ifland Timor, of fuch an height, that a flamy Spire or Pyramid was feen for three hundred miles in the Sea. This in the year 1638 , had its very foundations fhaken, by an horrible Earthquake; and was wholly fwallow'd up, together with the Ifland, leaving nothing behind it, but an huge mighty Lake. So the Annals of the Jefuites Society relate. ${ }^{\dagger}$

\footnotetext{
${ }^{\dagger}$ It seems unlikely that the Jesuits had direct information about Timor. Before the 1630 s the nearest Catholic missionaries were Dominicans located on Solor. Their fort was taken over by the Dutch in 1613 and the Dominicans moved to Flores and had some success in Timor in the 1640s. Although the Portuguese had a presence on Timor there was no fixed establishment until 1663. In Ternate and Tidore the Portuguese, Spanish and Dutch traded power in the early $17^{\text {th }}$ century; by the 1630 s the Dutch were dominant everywhere except for small enclaves (the Portuguese in Oecussi (Timor) and the English in Macassar [Bassett 1958]). However, the Jesuits had a strong presence in the Philippines and Japan and no doubt travelled on numerous routes in the region.
} 
A more recent reference to the eruption of Timor is that from the wonderfully named Pessimist's Guide to History: an irresistible compendium of catastrophes, barbarities, massacres, and mayhem - from 14 billion years ago to 2007 [Flexner and Flexner 2008, p77]:

1638: Indonesian Volcano Explodes. Located on the island of Timor in modern-day Indonesia, the 10,500 foot volcano peak blew itself apart in a cataclysmic eruption, killing hundreds of people in the area.

Kircher's original statement contains both details of dubious veracity and a problem with the logic of an island disappearing to leave behind nothing but a lake, but it is clear the story has shifted somewhat in 350 years.

Our present concern is only with the 350-year progress of the account of the 1638 eruption of Timor through volcanological and other literature and the ways in which details have been added or changed ${ }^{*}$.

\section{Athanasius Kircher (1602-1680)}

In about 1618 Athanasius Kircher was enrolled to study at the Jesuit college in Mainz; by 1633, at the age of 32, he was in Rome. He had personal experience of the Calabrian earthquake in 1638, the eruption of Etna and, in the same year, climbed into the crater of Vesuvius. These journeys awakened his interest in "the incredible power of Nature working in subterranean burrows and passages" [Glassie 2012, p94]. For the next few years he worked on all manner of natural philosophy subjects [Glassie 2012, p99]. Jesuits and others in his network of correspondents around the world sent him astronomical observations, reports of unusual phenomena, specimens of flowers, animals, and shells [Glassie 2012, p113].

Mundus Subterraneus - a two volume tome of atlaslike proportions and ten years in the making [Baldwin 2004, p67]—was published in Amsterdam in 1665 [Glassie 2012, p183]. Another one of his many major works, China Illustrated, was published in 1667. It was not limited to China but was drawn primarily from reports of missionaries who had been travelling to the east since the 1570s; Glassie [2012, p201] described the book as "probably the single most important written source for shaping the Western understanding of China and its neighbours". Kircher was the most prolific Jesuit author (at least 30 books) of the mid-seventeenth century [Siebert 2004, p94].

The views below provide a range of assessments of the importance of Kircher as a scholar:

${ }^{*}$ A separate account which attempts to trace whether or not such an eruption may have occurred somewhere in the east, and an examination of the several possible locales is being prepared. Appendix B briefly introduces some of the possibilities.
As a general rule Kircher never ruined a good story with facts. ... he was also known for a tendency to embellish on his own behalf. (The other frequent complaint about him was more like the opposite: people said he was inclined to believe any spectacular story he heard) [Glassie 2012].

Or as an American historian, John Ferguson, wrote in 1906 "his works in number, bulk and uselessness are not surpassed in the whole field of learning" [Glassie 2012]. In 1643 René Descartes noted "The Jesuit is quite boastful; he is more of a charlatan than a scholar" [Glassie 2012, p108]. Another scholar suggested he often entered in "full plagiaristic mode" for pages and pages at a time [Glassie 2012, p141].

Such negative views are countered by those of numerous others scholars:

Each publication demonstrated his dizzying array of linguistic, paleographic, historical, and scientific skills, and each advertised his myriad inventions, possessions of strange and exotic artifacts, and mysterious manuscripts [Findlen 2004, p2].

Stephen Jay Gould, in a work demonstrating Kircher's contribution to the study of fossils, notes

[I]n spending so much time reading the Mundus Subterraneus and other works by Kircher, I have developed enormous respect, not so much for the power of his insights and assertions, but for the quality of his doubts, and for his willingness to grope and struggle with material that he understood only poorly by his own admission [Gould 2004, p235].

Waddell argues Kircher's aim was not necessarily to codify facts as expected by Royal Society experimentalists and others but to create probable imitations of Nature's secret realms and forces which, by extension, were controlled by Kircher and the Jesuits (and God?) [Waddell 2006, p4].

As Glassie [2012, p272], one of Kircher's biographers, summarised

[I]t's clear that the modern perspective is simply not the right one to take when it comes to Kircher and to the entire Kircherian enterprise. There's something to be said for his effort to know everything and to share everything he knew, for asking a thousand questions about the world around him, and for getting so many others to ask questions about his answers; for stimulating, as well as confounding and inadvertently amusing, so many minds; for having been a source of so many ideas - right, wrong, half right, half-baked, ridiculous, beautiful, and all-encompassing. 
While this background provides a variety of possible contexts, none of it helps with establishing the origin or veracity of Kircher's comment on the eruption of Timor.

Kircher gives his source as the Annals of the Jesuit Society. Jesuit letters, one of the main information sources in the vast Archivum Romanum Societatis Iesu (ARSI), grew out of an early recognition that it was essential to secure union among its members and close contact between subjects and superiors. The aim of letters was edification of members of the society and their guidance [Correia-Afonso 1969, p1-2].

Letters could take 5 or even more years to reach the addressee and return [Correia-Afonso 1969, p28]. From 1517 it was decided that a Provincial report should be sent yearly to the Society's headquarters, comprising accounts of the various houses of the Province. Extracts from these letters were gathered together, making up the history of the Society for that year [Correia-Afonso 1969, p6].

Five types of Jesuit letter can be distinguished (Lach [1965, p317-318], Correia-Afonso [1969, p9-10]):

1. those meant for the superiors of the Order-these are the most explicit and illuminating; they are the most realistic and detailed;

2. those meant for the members of the Society in general-these are more discreet in style, yet are written with a good deal of freedom and affectionate regard. They supply details regarding social life and customs and missionary work abroad;

3. those addressed to the public at large-these letters are more studied in style and their contents more carefully checked and edited;

4. letters addressed to personal friends within or outside the Society-contain interesting information about the author and his environment; sometimes published;

5. allied documents-not strictly letters; studies of life and customs of particular tribes, accounts of particular expeditions, history of noted stations etc.

The superiors of the Society insisted on accuracy and fidelity to truth on the part of their chroniclers*. Sensational effect was not what was wanted, but objectivity and reliability [Correia-Afonso 1969, p7]. Original letters from the east were usually in Portuguese, Spanish or Latin [Correia-Afonso 1969, p108]. It was quite common for three or more transcripts of the one letter to be sent separately to Europe as a precaution against loss at sea [Correia-Afonso 1969, p24].

The system of transcription by hand (as letters were passed around Europe) involved many delays and was likely to be the source of many inaccuracies [CorreiaAfonso 1969, p33]. Jesuit letters were edited in Europe

* Siebert [2004] provides an interesting account of Kircher's issues with Jesuit censorship of his writings with an apologetical and apostolic rather than an historical end in view, so the letters from the east were touched up, or summarised, or enlarged, or embellished [Correia-Afonso 1969, p35]. Even forgeries were put on the market [Correia-Afonso 1969, p159].

Thus, it is not clear that the event described by Kircher ever actually happened, if it occurred where it might have happened, or whether it had been embellished even before it came to Kircher's attention. A three-day search of the vast Archivum Romanum Societatis Iesu (ARSI) failed to identify Kircher's source. Nonetheless, versions of his account, with the source seldom acknowledged, have survived for more than 350 years.

\section{Methodology}

I first came across the account in Lamb's 1970 paper on the dust veil index and in the 1888 Krakatoa committee report. It seemed obvious (to me) that the information was incorrect and I was intrigued that the prestigious Royal Society of London had been wrong twice! At first I was curious as to how and where the story had begun. Later I was surprised that the story had persisted for so long and captivated by the ways in which the story had changed. Throughout, I hoped that I might be able to pinpoint just where the 'eruption of Timor' had occurred; while I have been unsuccessful in this endeavour Appendix B sets out some of the events I see as possibilities.

My exploration of the available literature on the 1638 eruption of Timor was not driven by any formal methodology. In effect, the available literature was searched for (i) sources that mentioned the 1638 eruption of Timor; and (ii) sources that might corroborate Kircher's account. In pre-internet days this included searches in various libraries (including those in Sydney, Cambridge, London, Seattle, Honolulu and Washington D.C) and requests for inter-library loans, not always successful and often available only on microfilm. The search was erratic and discontinuous, one source leading to another and another ... intermittently for nearly five decades ${ }^{\dagger}$. In the last decade or two when 'keyword' searches were possible 'Timor 1638' and 'Timor eruption' were the most fruitful, but worthwhile finds diminished in number. Despite the length of this search we can assume that only a limited proportion of the accounts of the 1638 eruption of Timor have been uncovered, particularly as sources in languages other than English have been inadequately sampled.

\footnotetext{
${ }^{\dagger}$ In 2006 a presentation 'An eruption in Timor in 1638 - separating fact from fiction' was made in Quito, Ecuador at the Cities on Volcanoes conference. This failed to elicit any new leads (though, interestingly, R W Johnson of Geoscience Australia (GA) reported that after the Boxing Day 2004 Aceh tsunami GA received reports, inter alia, of volcanoes erupting in Timor - about $3500 \mathrm{~km}$ from the earthquake epicentre).
} 


\section{Location OF Kircher's Timor}

Kircher [1665; 1669] clearly refers to the eruption being located on the island Timor, an island that we locate today at about $9^{\circ} \mathrm{S}, 125^{\circ} \mathrm{E}$ (Figure 1). Kircher, if he was even interested, probably had only a vague idea where Timor was located. However, Diego Ribero's map of the world of 1529 shows the Spice Islands and Lesser Sundas as far east as Timor and an "astoundingly accurate Southeast Asian mainland" [Suárez 1999, p102]. The Blaeu maps of the first half of the $17^{\text {th }}$ century also show Timor in approximately the correct position to the east of Sumatra and Java and south of the equator. Timor had been visited by European navigators as early as 1514 when Antonio Pigafetta was the first European to describe the island. Earlier, in 1511, Abreu and Rodriques coasted along the interlocked group of islands comprising Wetar, Timor, Alor, and Solor but it is unclear whether they sighted Timor.

Despite this knowledge it is apparent that Timor was not on the main route used by Europeans from Malacca to the Spice Islands with ships generally following the course Java - Batu Tara - Buru - then either to Banda or the Moluccas [Pires 1944, p204] (see Figure 1). However, Arab, Indonesian, and Chinese traders were also active in the area during the early part of the $17^{\text {th }}$ century and Kircher's information could have been derived (probably indirectly) from any of these.

While modern gazetteers (and Google Earth ${ }^{\mathrm{TM}}$ ) list only the one Timor, Varenius et al. [1683, p321] refers to two distinct Timors:

I Comprehend under the name of the Moluccoes, not only the Ifles of Ternate, Tidore, Motill or Timor, Machian, and Bachian, which are particularly called the Moluccoes; but likewife thofe of GiLOLo, of the Land of $\mathrm{PA}^{-}$ pous, which lie on the Eaft; of Celebes, which are on their Weft; of them of CERAM, of Flores, and Timor, which are towards their South, and feveral others thereabouts*.

It seems that Varenius et al. [1683] regard both the Timors described as located under the name 'the Moluccas'; today, we use 'Maluku' to refer to the Moluccas (Figure 1) but delineating a much more limited area than that described by Varenius.

Confusion as to which of the two Timors known at the time Kircher was writing about was maintained by Robert Hooke's [1705] reference to "Timor, one of the Moluccas" (Table 1), a reference continued by Georg Hartwig in 1871, and compounded by Mungo Ponton

${ }^{*}$ The exact authorship of this statement is unclear. There appear to be three possibilities: Bernhardus Varenius, noted as an author and a major figure in mid-1 $7^{\text {th }}$ century geography, died in 1650 . Nicolas Sanson, also identified as making additions to the manuscript and a prominent French cartographer, died in 1667. Richard Blome, an English engraver, cartographer and publisher is not acknowledged on the title page. See full title in the References. who referred to 'Timor, most easterly of these islands', the following year [Ponton 1872].

The island in Maluku which Varenius et al. [1683] call Timor, Varenius also calls Motir (a transposition of Timor), Motil, Motill, and Mothir. Varenius describes the isle as five or six leagues ${ }^{\dagger}$ in circuit (p322). This island is also named as 'Timor or Motir' on the Willem Janszoon Blaeu map of 1630, and similarly named on a 1764 French map (Figure 2). Astonishingly, Pigafetta in 1514 gave the latitude of Motir as exactly $0^{\circ}$, correct to within about $40 \mathrm{~km}$ [Suárez 1999, p145].

Today the island is known as Pulau Moti $\left(0.5^{\circ} \mathrm{N}\right.$, $127.4^{\circ} \mathrm{E}$ ) (Figures 1 and 2). As the spice islands of Ternate and/or Tidore, less than $40 \mathrm{~km}$ to the north, were populated by Europeans from 1578 [Lach 1965, p500], and as no Holocene activity from this volcano (Volcano Number 268063) have been recorded in the Smithsonian database ${ }^{\ddagger}$, it is unlikely that Moti is the source volcano or island in Kircher's story.

A third possibility for the location of Kircher's Timor also deserves consideration. Pires [1944, p203-204] notes that by the "Islands of Timor" is meant the great Timor Island and Sumba or Sandalwood Island. He also notes "All the islands from Java onwards are called Timor, for 'timor' means 'east' in the language of the country, as if they were saying the islands of the east" (Figure 1). Tibbets [1981, p501], examining Arab navigation in the Indian Ocean before the coming of the Portuguese, wrote: "The term Timor ... according to the texts includes the whole of the islands to the southeast of Jāwa but what is actually meant is all the islands south and east of Sumbawa and Sumba. Whether or not Flores is included it is impossible to tell".

Thus, it appears that there are (at least) three possibilities for the location of Kircher's Island Timor:

1. The island that we call Timor today located at $9^{\circ} \mathrm{S}$, $125^{\circ} \mathrm{E}$, with the eastern part forming the independent country of Timor-Leste, and the western part a portion of the Indonesian province of Nusa Tenggara Timur (as shown on Figure 1);

2. The small Pulau Moti, west of Halmahera and south of Pulau Tidore in Provinsi Maluku Utara (as shown on Figures 1 and 2);

3. A location somewhere in the island chain stretching from Sumbawa to Timor and beyond to $\mathrm{Pu}$ lau Yamdena (Provinsi Nusa Tenggara Barat, Nusa Tenggara Timur, and the southern part of Provinsi Maluku) (as shown on Figure 1).

\footnotetext{
${ }^{\dagger}$ The Shorter OED describes a league as "an itinerary measure of distance, varying in different countries but usually estimated at about 3 miles".

‡The Global Volcanism database at the Smithsonian Institution in Washington DC is the global repository for information about volcanic activity. The database records every known eruption in the world in the last 10,000 years. See ht tp: / / volcano. si . edu/search_ volcano.cfm
} 


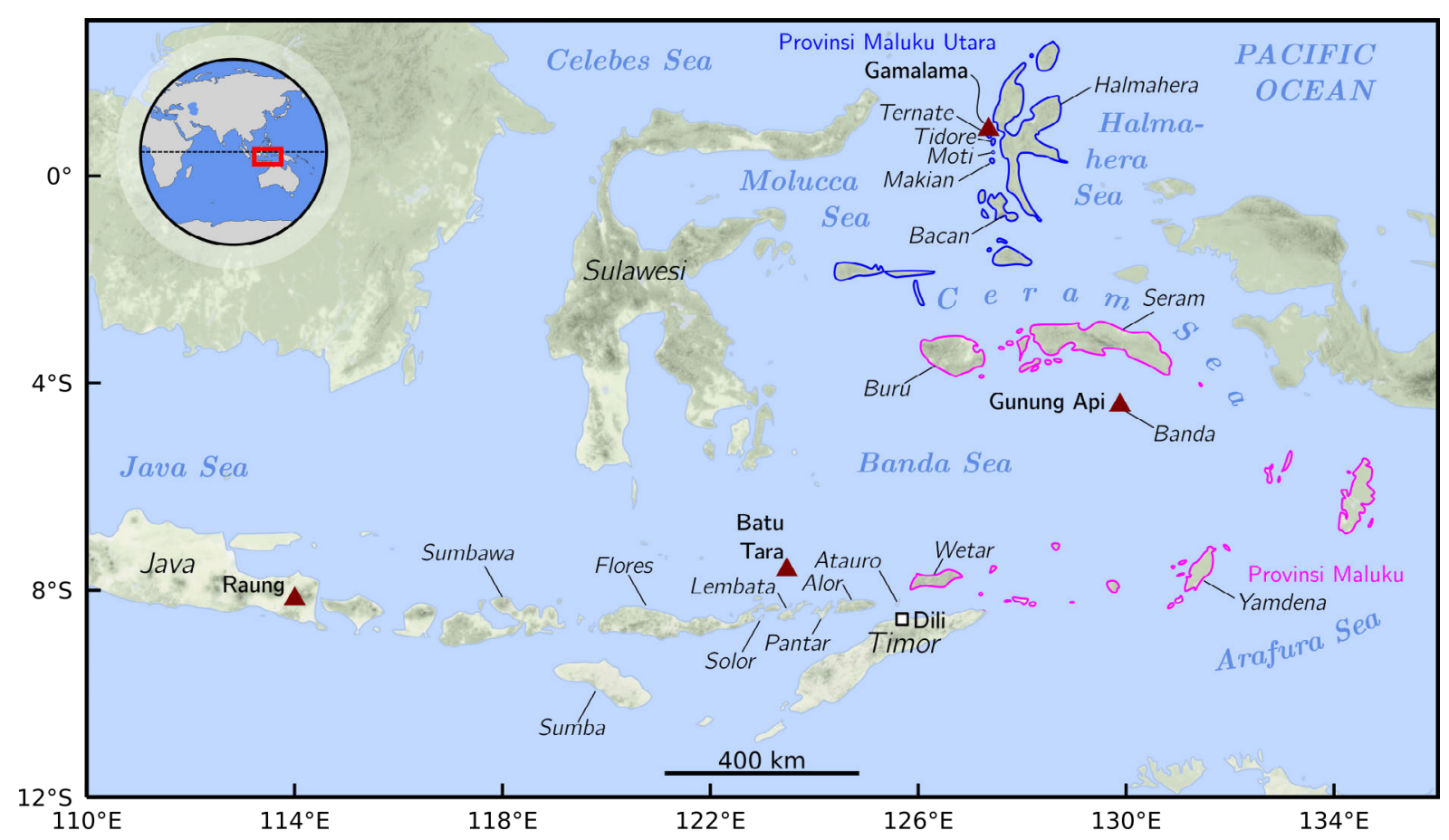

Figure 1: Eastern Indonesia showing Maluku the modern name for the Moluccas, with the islands of Provinsi Maluku Utara outlined in blue and those of Provinsi Maluku outlined in pink. The two Maluku provinces exclude Timor and Timor-Leste, West Papua/New Guinea, Sulawesi/Celebes, and Pantar and Alor which lie east of Flores (and north of Timor).

A fourth possibility-that Kircher was writing about a volcano called Timor-seems unlikely; Siebert et al. [2010]) include a gazetteer of thousands of volcano names and synonyms but none resemble "Timor".

However, two additional points deserve consideration. Firstly, during the $16^{\text {th }}$ and $17^{\text {th }}$ centuries there was intense competition for access to the Spice Islands (in particular Ternate, Tidore, Banda) in order to corner the market for pepper, cloves, mace and nutmeg. Spanish and Portuguese sources were often contradictory on the exact location of the Moluccas and the Philippines [Lach 1965, p501]; misinformation played an important part in this game, and it is possible that the information Kircher received was deliberately incorrect. On the other hand, for example, Pigafetta's estimate of the longitude of the Moluccas was markedly superior to the longitude that he assigned the Philippines - an illustration of the fact that although the direction of longitude was almost certainly politically influenced the fact that the figure was inaccurate was not necessarily deliberate. What we, in hindsight, might see as politically motivated deception of longitude may in fact have been simply the temptation to opt for the most advantageous figure within the range of possible truths. Errors in position stood for long periods-Varenius et al. [1683, p321], for example, gave the co-ordinates of the Isles of Moluccoes as straddling the Equator at $168^{\circ} \mathrm{E}$ longitude, whereas $128^{\circ} \mathrm{E}$ is more correct. Whether such 'errors' were deliberate or represent a selection most advantageous to a particular colonial power is now dif- ficult to determine [Lach 1965, p604].

Secondly, as early as 1793, Raspe pointed out that quite a lot of mistakes were made by authorities in translating unfamiliar names [Raspe 1970]*. As Pires [1944, p202] noted describing the ways names have changed from map to map: "All this shows once more how the cartographers, copying from map to map names they did not know, could disfigure them until they became almost unrecognizable and even meaningless". Further, as Suárez [1999, p133] wrote:

First-hand observers sometimes mistook part of an island to be a separate island altogether, while the map makers who plotted their data sometimes misconstrued distinct islands as different regions of a single island, or viceversa. Finally, explorers who searched for specific islands discovered and named by their predecessors often reached different islands but erroneously deemed them to be the original landfall, and then mapped the new island under the original name.

\section{SUBSEQUENT ACCOUNTS OF THE ERUPTION OF TIMOR}

All known accounts of the eruption of Timor have been collected in the Appendix A. Verbatim accounts

${ }^{*}$ Reference is to translation of 1793 edition 


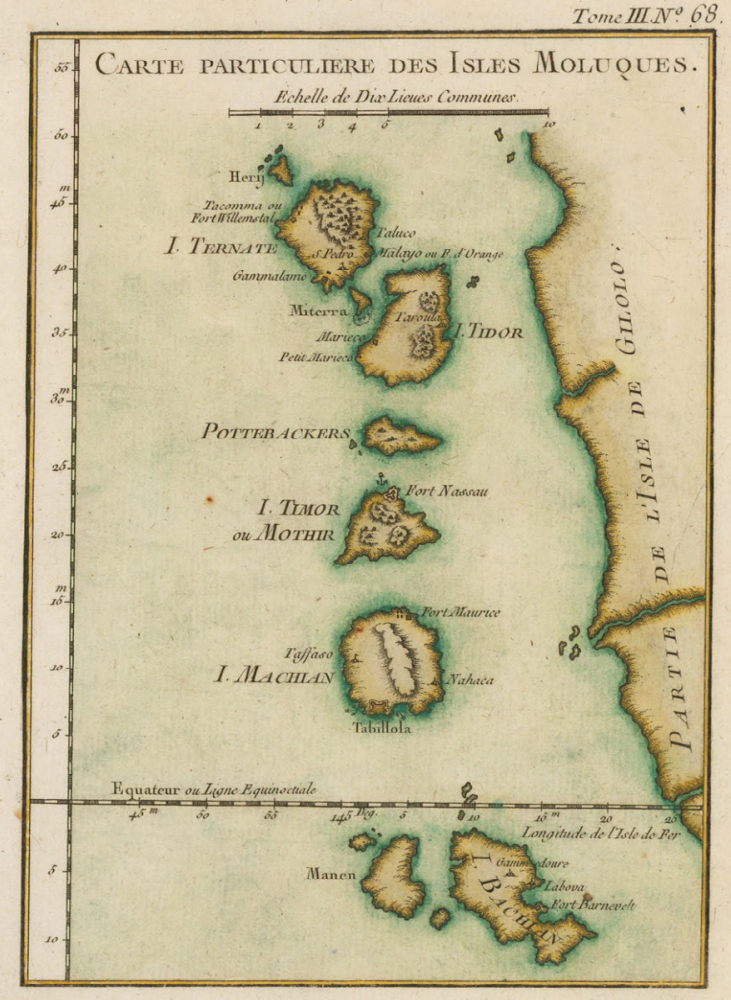

Figure 2: "Carte Particuliere des Îsles Moluques", by [Bellin 1765]. Published in Prévost L'Histoire Générale des Voyages. The stratovolcano on Mothir/ Moti/ Timor rises to a height of $927 \mathrm{~m}$ above sea level.

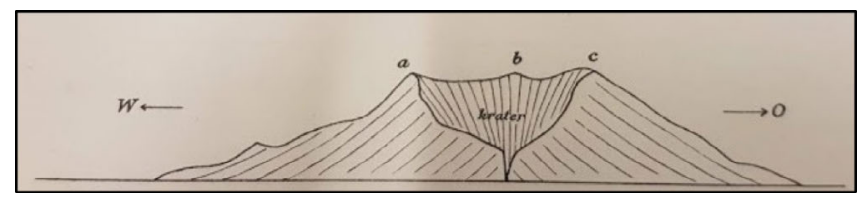

Figure 3: Moti drawn from the south [Verbeek 1908]. $\mathrm{W}=$ West, $\mathrm{O}=$ East [Oost $]$.

are given together, where appropriate, with translations into English. Translations have been performed by friends, colleagues and, in more than one case, by Google Translate (https://translate.google.com). The translations should be regarded as reasonably correct rather than perfect.

Table 1 summarises the information content of each of the 30 or so accounts contained in Appendix A under the major headings: Location, Height of the Peak, the year of the event, reference to an earthquake, the nature of volcanic activity, and the reported consequences of the event. Comparison of Table 1 with Appendix A shows that it is not always easy to 'categorize' an author's view. In the third column [Kircher 1665] cells marked in blue indicate the 'original' information items that stem from Kircher's account. Pink cells in columns to the right indicate that these items were also reported by subsequent authors. In most, but not all, cases subsequent editions of an author's work have been ignored. Blue cells in accounts later than 1665 identify new items of information additional to those supplied by Kircher. The second last row illustrates just how few authors provided a source for their information. Some of the main items in these accounts are considered in more detail below.

\subsection{Post-Kircher views on the location}

Although we can't be certain at this distance in time just which location Kircher's account actually refers to, subsequent writers rarely expressed any doubt. While we can judge it most likely that Kircher's story was referring to the Timor south of the Equator, $19^{\text {th }}$ century authorities become even more specific. Earl in 1845 locates an eruptive centre-not necessarily Kircher's 'flamy spire', on the north-east extreme of Timor-but then retracts in 1852 stating there are no active volcanoes in the eastern (Portuguese-controlled) part of the island ${ }^{*}$. In 1857 the Javanasche Courant places an eruption in the western (Dutch-controlled) half in 1856 at the mountain Iloen Bano, noting that "the account from which we are borrowing these details is all the more remarkable since it is the first notice of an eruption of a volcano in Timor, or at least the western part of the island" [as reported by Adams 1912].

As , p286-287 has shown the accounts of the 1856 and 1857 eruptions on Timor refer to one or more mud volcanoes, which have nothing to do with Kircher's original story. Bonney [1899, p230] also expresses the doubt that volcanoes exist in Timor, and doesn't mention the eruption of 1638 , but says there must be a few volcanoes "for one in the western part of the island is said to have been in eruption in 1856 and in the following year", noting there are also some mud volcanoes, "but nothing calling for special attention".

Mercalli, writing in 1907, pulls all the information together referring to the 1638 eruption and providing some details about the violent explosion at Floen-Bano [sic] in the western part of Timor on 26 December, 1856 and at Volcano Bibulito in May 1857. He then goes on to write: "Probably all these eruptions should be referred to one volcano which bears different names".

Schneider [1911] follows Mercalli, incorrectly naming the volcano Floen-Bano, and giving the dates of eruption as 1638, 1856, and 1857. Although Mercalli stated the volcano was located in the western part of the island, Schneider locates it in the eastern part, shows the location on a map (his Figure 32), places the volcano at $126^{\circ} 30^{\prime} \mathrm{E}, 8^{\circ} 50^{\prime} \mathrm{S}$ and states the height of the volcano as $2400 \mathrm{~m}$. This location is near the south coast about $110 \mathrm{~km}$ ESE of Dili, the capital of Timor-Leste, whereas Schneider's map shows the volcano located near the north coast about $130 \mathrm{~km}$ east of Dili.

\footnotetext{
${ }^{*}$ Details for each example cited here are given in Appendix A.
} 
Table 1 - A summary of the main features included in each account as detailed in Appendix A. Blue cells $=$ new information added at this time. Pink cells $=$ this item is included in the account published in this year. Clear cells $=$ no information about this item included in the account published in this year.

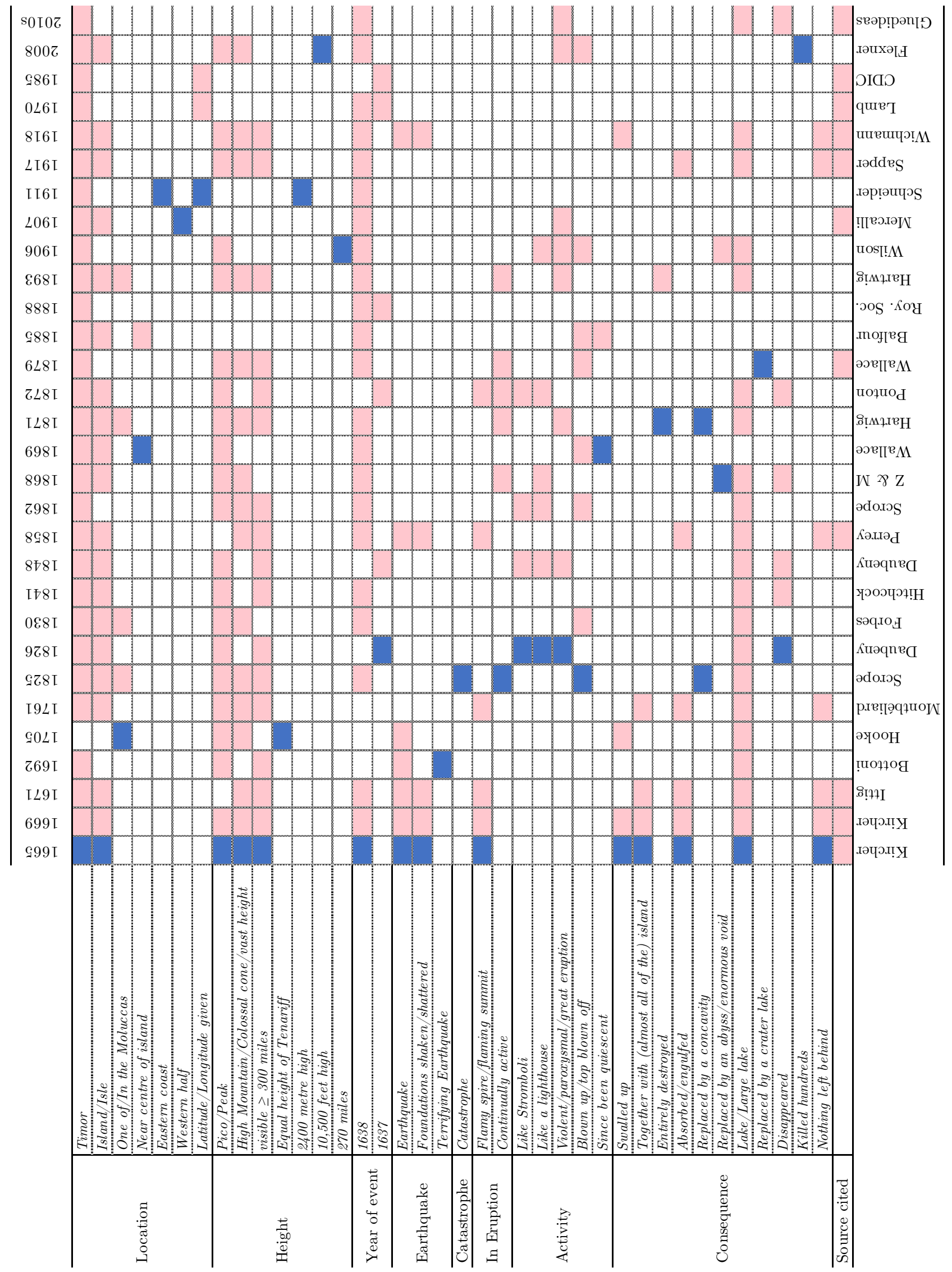


Worcester [1914-1915], a professor of zoology, provides a review of Adams [1912] and follows Adams in believing that Scrope obtained his information from Ittig's 1671 work and that the eruption was likely on a neighbouring island. However, he then finds Adam's view that there are no volcanoes on Timor a sweeping statement as he (Worcester) is "cognisant of the fact that there were eruptions from Timor as recently as 1856 and 1857". It appears either Worcester failed to read Adams' work carefully or that he believes that an eruption from a mud volcano is, in fact, a volcanic eruption.

Subsequent writers until the publication of Lamb's work in 1970, for example, Sapper [1917] and Wichmann [1918], repeat at least part of Kircher's account but are inclined to the view that there have been no volcanic eruptions on Timor.

It is easy to understand how many of the errors and misunderstandings listed above occurred. Timor was on the other side of the world for most authors and finding and verifying sources was often no easy matter in pre-internet days. Nonetheless, that in no way excuses the majority of authors from failing to state where their information came from. Table 1 shows just how few authors bothered to state their sources, and often borrowed almost verbatim chunks from earlier works without acknowledgement. The only author before Adams who provides first-hand information is Earl [1845; 1852] who lived in Timor, made observations, and then corrected them.

The one author referenced in Table 1 but left out of the above discussion is Alfred Russel Wallace, in a sense co-founder of the theory of evolution, resident of Timor for some months in 1861, an explorer, naturalist and resident in the area between Malaysia and westernmost New Guinea from April 1854 to January 1862, and author of The Malay Archipelago 1869. Despite Wallace's all-consuming focus (at this stage of his life) on the variety of species of animals and insects and his familiarity with Maluku landscapes and ecology, he too believed that Timor had a volcano, near the centre of the island. At the same time he recognised that Timor consisted of "ancient stratified rocks" [Wallace 1869, p18] and noted "it seems to form the termination of the great range of volcanic islands which begins with Sumatra, more than two thousand miles to the west" [Wallace 1869, p184]. He continues: "In no other part of Timor do there appear to be any recent igneous rocks, so that it can hardly be classed as a volcanic island. Indeed its position is just outside of the great volcanic island, which extends from Flores through Ombay and Wetter [Alor and Wetar: see Figure 1] to Banda".

We do not know why Wallace in his 1869 Malay Archipelago thought Timor had a central volcanic peak despite his own observations and instincts. However, Wallace also edited and extended the 1879 edition of Stanford's Compendium of Geography and Travel, and there he makes it quite clear it was one of the widely read works of George Julius Poulett Scrope (first published in 1825) which led him to follow more than 200 years of misrepresentation about an eruption in Timor.

\subsection{The Mountain Pico, seen for 300 miles in the sea}

Kircher [1665; 1669] reported that "a flamy Spire or Pyramid waf feen for three hundred milef in the Sea". If we use a simplified equation illustrating the effect of the curvature of the earth on distant observations ${ }^{*}$, for a flamy spire to be just seen at a distance of 300 nautical miles, Pico would have to be nearly 20,000 metres high. If the 300 miles refers to statute miles instead of nautical miles, the necessary height reduces to about 15,000 metres. As Mount Everest is about 8,850 metres high, either would seem to be a significant exaggeration. Rinjani on Lombok, the second highest volcanic mountain in east Asia, reaches an elevation of $3726 \mathrm{~m}^{\dagger}$.

In the decades before Kircher was writing, Pico de Teido on Tenerife in the Canary Islands, was believed by many, including many Jesuits, to be the highest mountain in the world ${ }^{\ddagger}$. Hooke [1705] compares the height of Pico, in the Moluccas, to that of Tenariff. The volcano on Tenerife has a height of $3715 \mathrm{~m}$.

If the sighting refers to a reflection of a fiery eruption on the cloud base, 15,000 $\mathrm{m}$ seems possible as high clouds in the tropics range about 6,000-18,000 $\mathrm{m}$ above sea level.

As Table 1 shows, 16 of the 30 authors included in this survey describe the peak as a 'high mountain' or 'colossal cone'. Seventeen authors, usually the same ones, describe the peak as being seen at a distance of 300 miles. Two other distances at which the peak could be seen are mentioned: Wilson [1906] suggests 270 miles, and Mercalli [1907] allows $450 \mathrm{~km}$ (roughly 280 statute miles). Flexner and Flexner [2008]) opt for a height of $10,500 \mathrm{ft}(\sim 3200 \mathrm{~m})$.

\subsection{Volcanic activity}

Only six authorities refer to a 'flamy spire' or 'flaming summit' : the four publications by Jesuits in the $17^{\text {th }}$ century, Perrey writing in 1858 a who also cites a Jesuit source, and Ponton [1872] who gives no source for his information.

Scrope [1825] extends the notion of a 'flamy spire'

${ }^{*} h_{1}=0.228(D-5)^{2}$ where $h_{1}$ is the cut-off height and $D$ is the total distance in nautical miles from a ship to Pico [Blong et al. 2016].

${ }^{\dagger}$ Gunung Kerinci in Sumatra is the highest volcano in Indonesia at about $3800 \mathrm{~m}$.

‡Jesuit Fathers wrote on the "pico" of Canarias, island of Tenerife, in 1556 [Wicki 1954, p494], as the highest or nearly so, mountain of the world; again in 1566 [Wicki 1960, p787]; also Fr Thomas Stephens, in 1579 [Wicki 1970, p683]. I am grateful to the late Fr Joseph Wicki, SJ, Jesuit Historical Institute, Rome, for this information. Interestingly, Varenius et al. [1683, p49] wrote: "El Pico in Teneriff, esteemed the highest in the whole World, whose top is conspicuous at Sea 60 miles". He also notes that Pico de St George in the Azores is reported to have "an equal Altitude with the Mountain of Teneriff". 
to 'continually active'; perhaps there is an implication in Kircher that the flamy spire had been seen more than once, but Scrope's account represents a significant escalation in volcanic activity. This theme is continued by five more authors in the $19^{\text {th }}$ century, while Daubeny [1826] extends the metaphor further introducing 'like a lighthouse' and 'like Stromboli'. Daubeny is also the first to use the word 'volcano', though the volcanic nature of the Pico of Timor is implied in Kircher's 'flamy spire'.

Scrope [1825] and Daubeny [1826] also enlarge the volcanic nature of the Pico, the former reporting that it was "blown up" (and a "catastrophe"), the latter referring to a "violent eruption". One or other of these themes is continued by almost all $19^{\text {th }}$ century reporters up to and including Mercalli [1907]. Wallace [1869], fortified by his personal knowledge of Timor, is able to report that Timor Peak was "blown up" in the 1638 eruption "and has since been quiescent".

While very few authors cite the source of their information, Table 1 indicates the authors who introduced new information to Kircher's saga (blue cells) and those that continued reporting specific elements of the story (pink cells).

\subsection{Earthquake}

The volcanic emphasis of all the $19^{\text {th }}$ century and later accounts is all the more remarkable in that Kircher's and subsequent early accounts are focused on the earthquake, rather than the eruption; as Kircher [1669] noted Pico "had its very foundationf fhaken, by an horrible Earthquake". All $17^{\text {th }}$ and $18^{\text {th }}$ century accounts describe the earthquake as "terrifying" or "shaking/ shattering" the foundations of the Pico/ Peak. The only subsequent accounts that mention an earthquake are those of Perrey [1858a] and Wichmann [1918], both of whom cite Jesuit sources*.

This change in emphasis from earthquake to eruption appears to begin with Scrope [1825] and Daubeny [1826] and indicates that most subsequent accounts probably relied on one or other of these widely-read popular authors for their unsubstantiated information.

\subsection{Consequences}

Kircher $[1665 ; 1669]$ makes clear that the foundations of the Pico on the island Timor were severely shaken; the mountain was "wholly fwall'ed up, together with the ifland, leaving nothing behind it, but an huge mighty lake". In other words, the mountain and the island disappeared beneath the sea. It seems illogical to refer to a mighty lake remaining, but perhaps this is

${ }^{*}$ Wichmann [1918, p31] appears not to really believe the account and notes that he has been unable to source the original $17^{\text {th }}$ century German accounts which he relied on. I have not found these accounts either. just an expression for the sea. If we compared this event with the minor eruption of Ritter Island in the Bismarck Sea in 1888 and the associated debris avalanche which left just a small sliver of the island remaining above sea level [Johnson 1987; Micallef et al. 2017], Kircher's description seems less incredible or unimaginable. Of course, if Kircher was referring to the modern island of Timor south of the equator, the description is fanciful.

The part of Kircher's description which has most captured the imagination of subsequent writers is the reference to the huge lake; 19 of the 28 later writers refer to this lake (Table 1), while many fewer authors use expressions such as "disappeared" or "nothing left behind" or "entirely destroyed". Scrope [1825] attempts to avoid any illogicality by referring to "replaced by a concavity" but he abandons this too in later editions. Wallace [1869] is the first author to mention no consequences. No authors mention a tsunami, a quite probable consequence of a sudden earthquake or eruptioninduced collapse of a large "flamy spire" on an island.

Only Flexner and Flexner [2008] considers consequences for humans, reporting that the cataclysmic eruption killed hundreds of people in the area. While this consequence seems based entirely on imagination, perhaps owing something to the 2004 Aceh (Sumatra) earthquake and tsunami, it makes reasonable sense; one wonders why earlier authors had not thought to mention consequences for humans.

\subsection{Year of the event}

Almost all accounts assume the eruption of Timor, following Kircher [1665; 1669], occurred in the year 1638. However, Daubeny [1826] introduced the idea that the eruption occurred in 1637. Whether this was an accidental error or a view including information from an additional source unknown to us we cannot discern.

It is possible that Daubeny thought that Kircher's Catholic source in the Annals of the Society of Jesus would have used a Gregorian calendar date, a calendar not adopted by England until 1752. It is also possible that Daubeny had information suggesting the eruption' occurred in the first three months of the year, a period (1st January-25 ${ }^{\text {th }}$ March) that formed part of the previous year until England switched from the Julian calendar to the Gregorian, again in 1752. It is also possible that Daubeny's information, from a source we are unaware of, had already switched the date from 1638 to 1637 , and that Daubeny himself knew nothing of this change.

However, it seems much more likely that Daubeny made a simple error in ascribing the event to 1637 and that this 'error' was repeated in the 1848 edition of his A description of active and extinct volcanos, or earthquakes, and of thermal springs, copied by Ponton in 1872, and continued in the Royal Society report on the Krakatau eruption of 1883 [Symons et al. 
1888], and Lamb's major work on the Dust Veil Index [Lamb 1970]. However, both the 1888 and 1970 reports give the date as $1637-1638$, suggesting they used more than one source for their information. Interestingly, the 1985 Carbon Dioxide Information Center (Oak Ridge National Laboratory) version of Lamb's 1970 Royal Society paper reverts to just the 1637 date.

While this 1637 'error' in dating the Timor event is of little consequence, it does establish a chain of unacknowledged plagiarism from Daubeny [1826] to the Royal Society [Symons et al. 1888], with subsequent authors acknowledging the 1888 source.

\section{Overview}

Table 1 suggests that Kircher's accounts contain 14 information items (1665, blue cells). The dotted line in Figure 4 shows the proportion of these 14 items that have been repeated in the various accounts over the last 350 years. Only once in the mid- $18^{\text {th }}$ century, once in the mid- $19^{\text {th }}$ century, and in Wichmann's early $20^{\text {th }}$ century version [Wichmann 1918] have accounts contained more than $50 \%$ of these items. The solid line in Figure 4 indicates the total number of information items in each account as a proportion of those in Kircher's accounts; thus, it is possible for an account to exceed $100 \%$ if all of Kircher's items were included and a few new details added. No account achieves this, but the dubious honour of producing the biggest 'gaps' between the original and the current account is achieved by Scrope [1825] who introduced four new items, and Daubeny [1826] who added six new items.

\section{Limitations}

Possibly it is unfair to suggest that Scrope, Daubeny and others have shown the most imagination in adding to or diverging from Kircher's account. Some authors may have found new sources of information (which they have failed to acknowledge), or more precise (or likely) terminology was introduced due to advanced understanding of volcanic eruptions.

This overview is also unfair in that it probably downplays the role of several authors in spreading elements of Kircher's story and/ or in disseminating diverging information about the eruption of Timor. In Table 1, Appendix A and Figure 4 we have, at the most, included only two editions of each author's work. This almost certainly undervalues the broad influence of Scrope and Daubeny as extremely popular authors on volcanology. For example, Charles Daubeny's A description of active and extinct volcanos: with remarks on their origin, their chemical phrenomena, and the character of their products, as determined by the condition of the earth during the period of their formation: being the substance of some lectures delivered before the University of Oxford, with much additional matter, first published in
1826, has been through 43 editions in English and German, with the most recent in 2014 (http: / / worldcat. org/identities/lccn-no89017152/). While the number of editions of George Poulett Scrope's Considerations on volcanos ... [1825] and Volcanoes ... [1862] is not known, his less popular The geology and extinct volcanos of central France [1858] has been published in 35 editions (http://worldcat.org/identities/ lccn-n84074013/). Both the Scrope and Daubeny books of interest here are still in print. Their contribution to the story of the eruption of Timor has been far larger than the analysis here suggests, and it is possible that their published works are still contributing to $21^{\text {st }}$ century versions of the eruption of Timor in 1638.

\section{Conclusions}

Kircher's account of the eruption of Timor was repeated in a few other publications by Jesuits in the $17^{\text {th }}$ century. A search of the literature, with all its limitations, suggests there were few reports in the $18^{\text {th }}$ century. Then in the $19^{\text {th }}$ century there is an outpouring of accounts with numerous embellishments, the former likely reflecting the romanticism of nature common at that time. These additions turn the story of a flamy spire into a continuing Stromboli-like eruption, and imply that an eruption, possibly seen only once, became a lighthouse for navigators. At the same time that the story is 'improved' by an enhanced understanding of the way some volcanoes erupt more or less continuously, the fiction that the eruption can be seen from a distance of 300 miles is maintained. At the same time, Kircher's emphasis on a 'horrible earthquake' is neglected and the new focus is on a violent or paroxysmal eruption or the volcano being blown up.

In the late $19^{\text {th }}$ and early $20^{\text {th }}$ centuries some commentators know enough about Timor to dismiss the story, confidently stating that there are no volcanoes on Timor, though there are still doubters adding dubious locations for the 1638 eruption and creating histories that combine a 1638 event with later 'explosions' from mud volcanoes.

Nonetheless the 1883 eruption of Krakatau and the associated global atmospheric phenomena lead to the compilation of a list of the principal volcanic eruptions between 1500 and 1886 by the Royal Society. This included the 1637-1638 eruption of Timor and led to a new phase of interest in dust veil indices and extended reports of the eruption until at least 1985, albeit without any of the details of a flamy spire, horrible earthquake, "swall'ed up", engulfed, or a large lake.

While the evidence is at best slender, the $19^{\text {th }}$ century interest in volcanic eruptions probably owes much to the writings of Scrope and Daubeny and the numerous editions of their popular books which remain in print even today. As Table 1 indicates most of the additional/new misinformation, indeed the corruption 


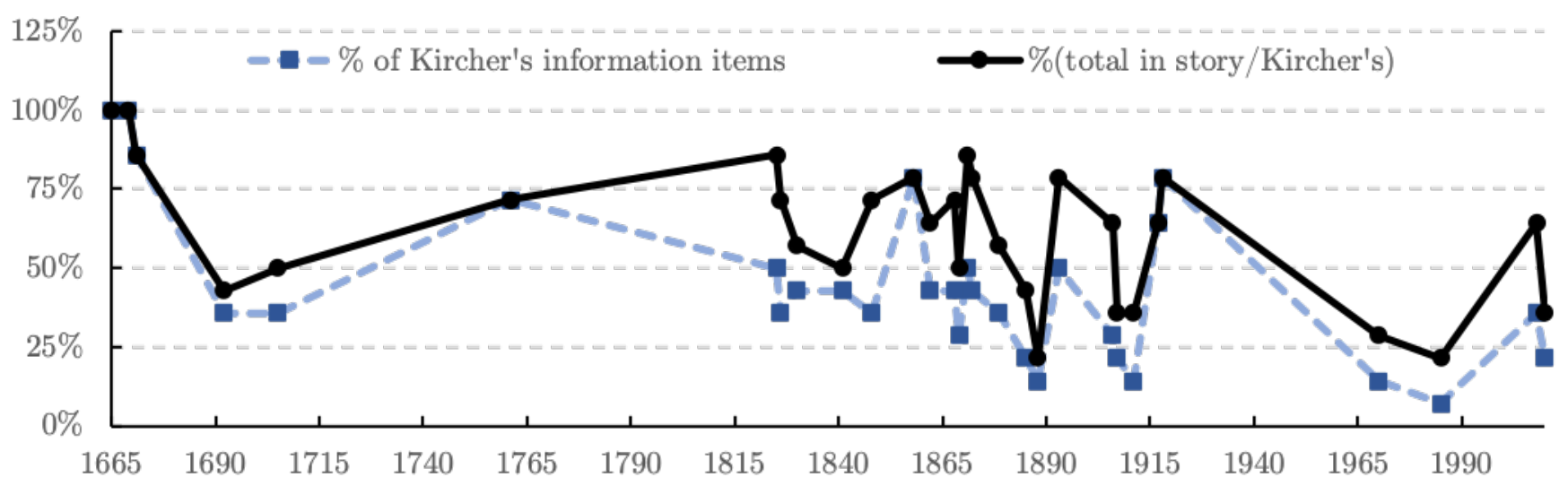

Figure 4: The dotted line indicates the proportion of Kircher's original information items retained in each account during the following 350 years. The solid line compares the number of information items in the account, with the number in Kircher's account. Thus, the difference between the two lines shows the proportion of the account that owes nothing to Kircher.

of Kircher's account of the eruption of Timor, appears to stem from these two writers. While these two authors popularised, and 'modernised' the eruption story to some extent with references to Stromboli, "like a lighthouse", "blown up", and "violent eruption", like so many others they failed to indicate their sources of information.

As Correia-Afonso [1969, pxxii], noted:

Much of the perverted history of the past owes its origin to the unscholarly if time-saving device of passing on statements obtained at second- or third-hand, without checking them even when this could be done with ease, and often without mentioning their purloined origin.

This plea is all too true, but would the course of Kircher's story about an eruption on Timor in 1638 have been very different over the last 350 years if sources had been quoted? The story would probably have continued much as it did-embellished and misunderstood. A story, possibly true, about a horrible earthquake on a flamy spire and the disappearance of a colossal cone would still have become a story about a paroxysmal eruption of a Stromboli-like, continuallyactive, volcano that collapsed. Essential as citations are in modern scholarship it seems difficult to assume that the plagiarism, embellishments, and misunderstandings that have characterised the 350-year history of the 1638 eruption of Timor would have been any fewer if every author had provided a source.

Our best chance of understanding more about the 'eruption of Timor in 1638' probably lies in the Archivum Romanum Societatis Iesu (ARSI) in Rome. While opinions about Athanasius Kircher range from 'charlatan' to 'genius' he did provide a source for his information about the eruption. But did he report his source accurately, embellish the information, or misunderstand it?

\section{Acknowledgements}

As my interest in the 1638 eruption of Timor has extended for nearly five decades, I am indebted to many scholars for assistance and thoughtful advice. With the passage of time, many of them are no longer with us: Fr Joseph Wicki, S.J., Jesuit Historical Institute, Rome; Fr Hubert Jacobs, S.J., Jesuit Historical Institute, Rome; Professor C R Boxer, Little Gaddesden, Herts., UK.; Professor Anthony Disney, La Trobe University; Professor C R de Silva, University Park, Sri Lanka; Professor Dauril Alden, University of Washington; Professor Jim Fox, ANU; and Professor Jack Golson, ANU - the latter for his role as a sounding board in so many things volcanic and archaeological.

I am also deeply indebted to Lucinda Coates for innumerable ferreting forays to the Macquarie University library, and to a large number of anonymous librarians at Macquarie University, University of Washington (Seattle), the Mitchell Library (Sydney), the British Museum Library (London), and at the University of Cambridge, and the Australian National Library (Canberra). My thanks also to Camilla Russell and her colleagues who introduced me to the Archivum Romanum Societatis Iesu (ARSI) in Rome.

I am most grateful to Laurie Drake, S.J., Ron Paton, Sandra Schuster, and Michael Barkhausen for various translations and to Rosemary Saul and Belinda Chambers who typed and retyped my vast notes on the eruption of Timor as the word processing art changed over several decades last century. My sincere thanks to Qianyang Chen who can do things with spreadsheets that I can only dream about.

This report has benefited enormously from the editorial process. Alison Jolley, for Volcanica, has provided friendly, positive comment and suggestions as has an anonymous reviewer. Finally, I would like to thank most seriously Kenneth L. Taylor, Emeritus Professor in the Department of History of Science, University of 
Oklahoma, for his kindly, encouraging, insightful comments that have not only enhanced the paper but also markedly improved my understanding of Athanasius Kircher and seventeenth century science. I am also extremely grateful to Jamie Farquharson for producing Figure 1, and to those who made sense of the partial references I provided for a number of early manuscripts.

This work has not been supported by any funding bodies.

\section{Data aVailability}

All necessary data are included in Appendix A.

\section{Copyright Notice}

C The Author(s) 2019. This article is distributed under the terms of the Creative Commons Attribution 4.0 International License, which permits unrestricted use, distribution, and reproduction in any medium, provided you give appropriate credit to the original author(s) and the source, provide a link to the Creative Commons license, and indicate if changes were made.

\section{REFERENCES}

Adams, G. (1912). "Timor Island; its supposed volcano and its probable tectonic relations". Philippines Journal of Science 7A.4, pp. 283-289.

Baldwin, M. (2004). "Reverie in Time of Plague: Athanasius Kircher and the Plague Epidemic of 1656". The last man who knew everything. . or did he?: Athanasius Kircher, SJ (1602-80) and His World. Ed. by P. Findlen. London: Routledge, pp. 63-77.

Balfour, E. (1885). The Cyclopredia of India and of Eastern and Southern Asia: Commercial, Industrial and Scientific, Products of the Mineral, Vegetable, and Animal Kingdoms, Useful Arts and Manufactures. Vol. 3. London: B. Quartitch.

Barnes, R. H. (1982). "The Majapahit dependency Galiyao". Bijdragen tot de Taal-, Land-en Volkenkunde 4, pp. 407-412.

Bassett, D. K. (1958). "English trade in Celebes, 16131667". Journal of the Malayan Branch of the Royal Asiatic Society 31.1, pp. 1-39.

Bellin, J. N. (1765). Carte Particuliere des Îsles Moluques. Paris. [Scale 1: 620,000 ].

Blong, R., S. Fallon, R. Wood, C. McKee, K. Chen, C. Magill, and P. Barter (2018). "Significance and timing of the mid-17th-century eruption of Long Island, Papua New Guinea". The Holocene 28.4, pp. 529-544. DoI: $10.1177 / 0959683617735589$.

Blong, R., J. Kemp, and K. Chen (2016). "Dating the Last Major Eruption of Long Island, Papua New Guinea: The Evidence From Dampier's 1700 Voyage on theRoebuck". Terrae Incognitae 48.2, pp. 139-159. DoI: $10.1080 / 00822884.2016 .1211354$.

Bonney, T. G. (1899). "Volcanoes: their Structure and Significance". Nature 60.1541, pp. 27-28. DoI: 10 . 1038/060027b0.

Bottoni, D. (1692). Pyrologia topographica, id est De igne dissertatio Juxta loca cum eorum descriptionibus. Napoli: In publico Neapolitino Gymnasio Primarii Philosophi\{ae. [In Latin].

Boxer, C. R. (1947). The topasses of Timor. 24. Amsterdam: Indisch Instituut.

Correia-Afonso, J. (1969). "Jesuit letters and Indian history, 1542-1773". Studies in Indian history and culture of the Heras Institute of Bombay. 2nd. Vol. 20. Bombay: Oxford University Press.

Daubeny, C. (1826). A description of active and extinct volcanos: with remarks on their origin, their chemical phenomena, and the character of their products. London: Philips and Parker.

- (1848). A Description of Active and Extinct Volcanos, of Earthquakes, and of Thermal Springs. London: Richard and John E. Taylor.

de Montbéliard, G. (1761). "Liste chronologique des Éruptions de Volcans, des tremblements de terre, de quelques faits météorologiques les plus remarquables, des cometes, des maladies pestilentielles, \&c. jusqu'en 1760. tirée des Mémoires des Académies de l'Europe, des Ouvrages périodiques des Histoires générales \& des Relations particulières". Collection académique composée des mémoires, actes ou Journaux des plus célébres Académies, pp. 488-681. [In French]. Earl, G. W. (1845). "On the Physical Structure and Arrangement of the Islands of the Indian Archipelago". Journal of the Royal Geographical Society of London 15, p. 358. Dor: $10.2307 / 1797916$.

- (1852). "Contributions to the physical geography of south-eastern Asia and Australia". The Journal of the Indian Archipelago and Eastern Asia 6.5, pp. 243-277. Findlen, P. (2004). "Introduction". The last man who knew everything... or did he?: Athanasius Kircher, SJ (1602-80) and His World. Ed. by P. Findlen. London: Routledge, pp. 1-48.

Flexner, D. and S. B. Flexner (2008). The Pessimist's Guide to History: An Irresistible Compendium of Catastrophes, Barbarities, Massacres, and Mayhem-from 14 Billion Years Ago to 2007. 3rd. Harper Collins.

Forbes, J. D. (1830). "Physical Notices on the Bay of Naples:-No. 6. the Bay of Baja". The Edinburgh Journal of Science 2, pp. 75-102.

Glassie, J. (2012). A man of misconceptions: the life of an eccentric in an age of change. New York: Penguin.

GluedIdeas.com (n.d.). Volcanoes. URL: http : / / gluedideas . com / content - collection / cyclopedia-of-india-3/Volcanoes_P5.html (visited on 11/11/2019). [Free Resource of Historical Information: Cyclopedia of India, Volume 3]. 
Gould, S. J. (2004). "Father Athanasius on the Isthmus of a Middle State: Understanding Kircher's Paleontology". The last man who knew everything... or did he?: Athanasius Kircher, SJ (1602-80) and His World. Ed. by P. Findlen. London: Routledge, pp. 207-237.

Hartwig, G. (1871). The subterranean world. London: Longmans, Green and Co.

- (1887). Volcanoes and Earthquakes: A Popular Description of the Movements in the Earth's Crust: from "The Subterranean World". London: Longmans, Green and Co.

Hitchcock, E. (1841). Elementary Geology. New York: Dayton and Saxton.

HMSO (1920). Dutch Timor and the lesser Sunda Islands. London: His Majesty's Stationery Office. [Handbook prepared under the direction of the historical section of the Foreign Office, No 86].

Hooke, R. (1705). Lectures and discourses of eathquakes and subterranean eruptions. Explicating the causes of the rugged and uneven face of the Earth, and what reasons may be given for the frequent finding of shells and other sea and land petrified substances, scattered over the whole terrestrial superficies. Ed. by R. Waller. London. [2nd ed., with a new introduction by T .M. Brown of Princeton University].

Ittig, M. T. (1671). De Montium Incendiis. Leipzig: Joh. Wittigau. [In Latin].

Johnson, R. W. (1987). "Large-scale volcanic cone collapse: The 1888 slope failure of Ritter volcano, and other examples from Papua New Guinea". Bulletin of Volcanology 49.5, pp. 669-679. Dor: 10 . 1007 / bf01080358.

Kircher, A. (1665). Mundus Subterraneus. Amsterdam: Joannem Janssonium \& Elizeum Weyerstraten. [In Latin].

- (1669). The Volcano's: or, Burning and Fire-vomiting Mountains, Famous in the world: With their RemarkABLES. Collected for the moft part out of KIRCHER's Subterraneous World; And expof'd to more general view in Englifh, upon the Relation of the late Wonderful and Prodigious Eruptions of Aetna. Thereby to occafion greater admirations of the Wonders of Nature (and of the God of Nature) in the mighty Element of Fire. London: J. Darby for John Allen.

Kuenen, P. H. (1937). "Geological results". Scientific results of the Snellius Expedition in the eastern part of the Netherlands East Indies, 1929-1930. Ed. by P. H. Kuenen, P. M. van Riel, J. P. H. Perks, F. Pinke, and H. Boschma. Lleiden: Brill.

Lach, D. F. (1965). Asia in the making of Europe, I: The century of discovery, Book 2. Chicago and London: The University of Chicago Press.

Lamb, H. H. (1970). "Volcanic dust in the atmosphere; with a chronology and assessment of its meteorological significance". Philosophical Transactions of the Royal Society of London. Series A, Mathematical and Physical Sciences 266.1178, pp. 425-533.
- (1985). Volcanic Loading, the Dust Veil Index. Tech. rep. Oak Ridge National Laboratory, TN.

Mennis, M. R. (1981). "Yomba Island: a real or mythical volcano?" Cooke-Ravian Volume of Volcanological Papers. Geological Survey of Papua New Guinea Memoir 10, pp. 95-99.

- (2005). Yomba Island (Hankow Reef) : Atlantis of the South Pacific : fact or fiction? Brisbane: Lalong Enterprises.

Mercalli, G. (1907). I vulcani attivi della terra: morfologia-dinamismo-prodotti-distribuzione geografica-cause. Milan: Ulrico Hoepli. [In Italian].

Micallef, A., S. Watt, C. Berndt, M. Urlaub, S. Brune, I. Klaucke, C. Böttner, J. Karstens, and J. Elger (2017). "An 1888 Volcanic Collapse Becomes a Benchmark for Tsunami Models”. Eos. Dor: 10. 1029/ 2017 eo083743.

Neumann van Padang, M. (1951). "Catalogue of the active volcanoes of Indonesia, Part I". Catalogue of the active volcanoes of the world including solfatara fields. Napoli: International Volcanological Association.

Perrey, M. A. (1858a). "Sur le Bibiluto: Volcan de LÎle de Timor". Nouvelles Annales des Voyages, de la Géographie, de l'Histoire, et de l'Archéologie 6.3. Ed. by A. Bertrand, pp. 129-136. [In French].

- (1858b). "Deuxième note sur les phénomènes seismiques à Timor". Nouvelles Annales des Voyages, de la Géographie, de l'Histoire, et de l'Archéologie 6.4. Ed. by A. Bertrand, pp. 303-305. [In French].

Pires, T. (1944). "The Suma Oriental of Tomé Pires: An Account of the East, from the Red Sea to Japan, written in Malacca and India in 1512-1515, and The Book of Francisco Rodrigues, Rutter of a Voyage in the Red Sea, Nautical Rules, Almanack and Maps, Written and Drawn in the East before 1515." Works issued by the Hakluyt Society. Ed. by A. Cortesão. Vol. 2. 90. New York: Routledge.

Ponton, M. (1872). Earthquakes and Volcanoes: Their History, Phenomena, and Probable Causes. London: T. Nelson and Sons.

Raspe, R. E. (1970). An introduction to the natural history of the terrestrial sphere, principally concerning new islands born from the sea, and Hooke's hypothesis of the earth, on the origin of mountains and petrified bodies, to be further established from accurate descriptions and observations. Latin and English. Ed. and trans. by A. N. Iversen and A. V. Carozzi. New York: Hafner Press Publishing Co. [Translation of Specimen historiae naturalis globi terraquei [1763]. Includes facsimile of 1783 edition.]

Sapper, K. (1917). "Katalog der geschichtlichen Vulkanausbrüche". Schriften der Wissenschaftlichen Gesellschaft in Strassburg 27, pp. iii-358. [In German].

- (1927). Vulkankunde. Vol. 3. Stuttgart: J. Engelhorns. [In German].

Schneider, K. (1911). Die vulkanischen Erscheinungen der Erde. Berlin: Gebrüder Borntraeger. 
Scrope, G. P. (1825). Considerations on Volcanos: The Probable Causes of Their Phenomena, the Laws which Determine Their March, the Disposition of Their Products and Their Connexion with the Present State and Past History of the Globe; Leading to the Establishment of a New Theory of the Earth. London: W. Phillips.

- (1858). The geology and extinct volcanos of central France. London: J. Murray.

- (1862). Volcanos: the Character of Their Phenomena, Their Share in the Structure and Composition of the Surface of the Globe, and Their Relation to Its Internal Forces. With a Descriptive Catalogue of All Known Volcanos and Volcanic Formations. 2nd. London: Longman, Green, Longmans, and Roberts.

- (1872). Über Vulkane. Der Charakter ihrer Phänomene, ihre Rolle in dem Bau und in der Zusammenfeßung der Erdoberfläche und iihre Beziehung zu den Kräften des Inneren. Berlin: Robert Oppenheim. [In German].

Siebert, H. (2004). "Kircher and His Critics: Censorial Practice and Pragmatic Disregard in the Society of Jesus". The last man who knew everything... or did he?: Athanasius Kircher, SJ (1602-80) and His World. Ed. by P. Findlen. London: Routledge, pp. 79-104.

Siebert, L., T. Simkin, and P. Kimberly (2010). Volcanoes of the World. 3rd. Berkely-Los Angeles-London: University of California Press.

Silver, E., S. Day, S. Ward, G. Hoffmann, P. Llanes, N. Driscoll, B. Appelgate, and S. Saunders (2009). "Volcano collapse and tsunami generation in the Bismarck Volcanic Arc, Papua New Guinea". Journal of Volcanology and Geothermal Research 186.3-4, pp. 210-222. Dor: 10 . $1016 /$ j . jvolgeores . 2009. 06.013.

St. John, H. S. R. (1853). The Indian archipelago: its history and present state. Vol. 2. London: Longman, Brown, Green, and Longmans.

Suárez, T. (1999). Early mapping of Southeast Asia: the epic story of seafarers, adventurers, and cartographers who first mapped the regions between China and India. Singapore: Periplus Editions.

Symons, G. J., J. W. Judd, S. R. Strachey, W. J. L. Wharton, F. J. Evans, F. A. R. Russell, D. Archibald, and G. M. Whipple (1888). The eruption of Krakatoa, and subsequent phenomena. London: Trübner \& Co.

The Royal Geographical Society (1913). "Tectonic Relations of Timor". The Geographical Journal 41.4, pp. 385-386. [with the Institute of British Geographers].

Tibbets, G. R. (1981). Arab Navigation in the Indian Ocean before the Coming of the Portuguese. Vol. 42. London: Royal Asiatic Society of Great Britain and Ireland. [Translation of Kitāb al-fawāidfı usūl albahr wa'l-qawā'id of Ahmad b. Mājid al-Najd1].

van Bemmelen, R. W. (1949). The Geology of Indonesia, Volume 1A, General Geology of Indonesia and Adjacent Archipelagoes. The Hague: Government Printing Office.
Varenius, B., N. Sanson, R. Blome, and F. Lamb (1683). Cosmography and Geography, in Two Parts: The First, Containing the General and Absolute Part of Cosmography and Geography, Being a Translation From That Eminent and Much Esteemed Geographer, Varenius. Wherein Are at Large Handled All Such Arts as Are Necessary to Be Understood, for the True Knowledge Thereof. To Which Is Added the Much Wanted Schemes, Omitted by the Author. The Second Part, Being a Geographical Description of the World, Taken From the Notes and Works of the Famous Monsieur Sanson, Late Geographer to the French King. To Which Are Added About an Hundred Cosmographical, Geographical and Hydrographical Tables of Several Kingdoms and Isles in the World, With Their Chief Cities, Seaports, Bays, Ec. Drawn From the Maps of the Said Sanson. London: Samuel Roycroft.

Vatter, E. (1932). Ata kiwan, unbekannte bergvölker im tropischen Holland. Leipzig: Bibliographisches Institut. [In German].

Verbeek, R. D. M. (1908). Rapport sur les Moluques: Reconnaissances géologiques dan la partie orientale de l'Archipel des Indes Orientales Néerlandaises. Vol. 1. 37. Batavia: Imprimerie de l'état. [Edition francaise du Jahrboek van het Mijnwegen in Nederlandsch OostIndië, 37, partie scientifique.] [In French].

Waddell, M. A. (2006). "The World, As It Might Be: Iconography and Probabilism in the Mundus subterraneus of Athanasius Kircher". Centaurus 48.1, pp. 3-22. DoI: 10.1111/ j.1600-0498.2006.00038. $\mathrm{x}$.

Wallace, A. R. (1869). The Malay Archipelago: The Land of the Orang-utan, and the Bird of Paradise. A narrative of travel, with studies of Man and Nature. London: Macmillan and Co.

Wallace, A. R. (1879). "Australasia”. Stanford's Compendium of Geography and Travel. Ed. by A. R. Wallace. Trans. by A. H. Kean. London: Edward Stanford. [Based on Hellwald's 'Die Erde und Ihre Völker].

Watt, S. F. et al. (2019). "From catastrophic collapse to multi-phase deposition: Flow transformation, seafloor interaction and triggered eruption following a volcanic-island landslide". Earth and Planetary Science Letters 517, pp. 135-147. Dor: 10 . 1016/ j.eps 1.2019.04.024.

Wichmann, A. (1918). The earthquakes of the Indian Archipelago until the year 1857. Vol. 20. 4. Amsterdam.

“Documenta Indica III (1553-1557)" (1954). Monumenta Historica SI 3. Ed. by I. Wicki. [In Latin].

"Documenta Indica VI (1563-1566)" (1960). Monumenta Historica SI 6. Ed. by I. Wicki. [In Latin].

“Documenta Indica XI (1577-1580)" (1970). Monumenta Historica SI 11. Ed. by I. Wicki. [In Latin].

Wilson, J. R. (1906). San Francisco's Horror of Earthquake and Fire: Terrible Devastation and Heart-rending Scenes... to which is Added Graphic Accounts of the Eruptions of Vesuvius and Many Other Volcanoes, Explaining the Causes of Volcanic Eruptions and Earthquakes. Memorial Publishing Company. 
Worcester, D. C. (1914-1915). "Review of recent vulcanological literature". Zeitschrift für Vulkanologie 1.1, pp. 126-127. [Includes review of The Royal Geographical Society article in Geographical Journal [1913], Vol. 41, pages 385-386].

Zurcher, F. and E. Margollé (2012). Volcanoes and earthquakes, ancient and modern. Trans. by W. Lockyer. Cambridge: Cambridge University Press. Dor: 10 . 1017 / cbo9781139226806. [Translation of 1868 edition published by Blackie and Son, London.]

\section{A Appendix 1}

Direct quotations from the named sources are inset. Inset items in [ ] are translations of the quotations. Paragraphs that are not inset are generally commentaries provided by the named authors.

Kircher [1665, p181]:

Erat \& alius in Timor Infula Mons Picus nomine, tantae altitudinus, ut per 300 milliaria flammeus in mari vertex fe confpiciendium praeberet; hic anno 1638 concuffis per horrendum terraemotum fundamentis una cum Infula abforptus, nil praeter ingentem lacum poft fe reliquit. Ita referunt Annales Soc. Jesu*.

Kircher [1669, p13]:

The Mountain Pico in the Ifland Timor, of fuch an height, that a flamy Spire or Pyramid was feen for three hundred miles in the Sea. This in the year 1638 , had its very foundations thaken, by an horrible Earthquake; and was wholly fwallow'd up, together with the Ifland, leaving nothing behind it, but an huge mighty Lake. So the Annals of the Jefuites Society relate.

Ittig [1671, p120]:

There was also, in the island of Timor, a mountain so high that its flaming summit was said to be visible three hundred miles at sea. In the year 1638 when its foundations were shattered by a terrible earthquake, together with the island, it was absorbed, leaving only a great lake in its place, as the annals of the Society of Jesus record. (translated from the Latin in Perrey [1858a] provided by Adams [1912, p287]).

Bottoni [1692, p239]:

Infulam Timor mons Picus per 300 mill. in mari confpicuus polt horribilem terremotum

${ }^{*}$ Kircher began work on Mundus Subterraneus perhaps a decade before 1665. In November 1657 he published Iter ecstaticum ii (Second Ecstatic Journey), a forerunner of Subterranean World [p67 Baldwin 2004]. I have been unable to find a copy of this book-possibly it refers to the eruption of Timor. afforbuit, lacufque folus remanfit, mirabilique evétu mare in terram converfum eft.

[The peak of the island Timor, conspicuous for 300 miles at sea, was absorbed after a terrifying earthquake; leaving only a lake, the miraculous event turned the land into the sea].

Hooke [1705, p307]:

The Pico in the Moluccas, accounted of equal height with that of Tenariff, was by a late Earthquake quite fwallow'd into the Earth, and left a Lake in its Place.

de Montbéliard [1761, p564]:

Le Pic de l'Isle Timor étoit si haut, qu'on voyait à la distance de 300 milles les flammes qu'il vomissoit; il fut englouti avec presque toute l'Isle, et ne laissa en sa place qu'un grand lac. [in Sapper 1917, p198].

[The Peak of Isle Timor was so high that the flames it vomited were visible at a distance of 300 miles; it was engulfed with almost all the Isle, and left in its place only a large lake].

Scrope [1825, p163]:

Such a catastrophe destroyed in the year 1638, a colossal cone called the Peak, in the isle of Timor, one of the Moluccas. The whole mountain, which was before this continually active, and so high that its light was visible, it is said, three hundred miles off, was blown up and replaced by a concavity now containing a lake.

Daubeny [1826, p322]:

In the Island of Timor, the volcano of the peak served, like that of Stromboli, as a sort of lighthouse, seen at more than 300 miles distance. In 1637, this mountain, during a violent eruption disappeared entirely: a lake at present takes its place.

Forbes [1830, p84]:

In 1638, an island had also been formed off St Michael's, and this year was rather remarkable for the occurrence of volcanic explosions. Not only this island was elevated, but we have already noticed that an eruption of pumice took place at the island of Santorini, and the Peak, a very lofty volcanic mountain in the island of Timor, one of the Moluccas, had its top blown off by an explosion the same year, and replaced by a lake. 
Hitchcock [1841]:

In 1638, the Pic, a volcano in the Island of Timor, so high as to be visible 300 miles, disappeared, and in its place is now a lake.

Daubeny [1848, p402]:

In the island of Timor itself the volcano of the peak served, like that of Stromboli, as a sort of lighthouse, seen at more than 300 miles distance. In 1637 this mountain ${ }^{*}$, during a violent eruption, disappeared entirely; a lake at present takes its place.

Earl [1852, p264]:

In the first half of this paper, reprinted from the Transactions of the Royal Geographical Society [Earl 1845, p358] Earl refers to an active volcano near the east end of Timor and refers to the chain of islands extending from Java to Timor as being of the same volcanic character. However, his accompanying map shows no active volcanoes on Timor and shows Timor as being amongst his "areas of upheaval" rather than amongst his "volcanic formations".

In my essay of 1845 I have pronounced the peaked mountain at the north-east extreme of Timor to be in a state of activity, having been induced to do so by the reports of natives of the adjacent island Kissa, and from my having on two several occasions seen the summit of the mountain in a state of ignition, but I have since been informed by gentlemen connected with the Portuguese settlements in Timor, that there are no active volcanoes in the eastern part of the island. I must therefore have been deceived by the burnings of the jungle which the natives make toward the close of the year, for the purpose of clearing new lands for cultivation.

\section{St. John [1853, p20]:}

With reference to Timor: "No volcanoes are found, and no traces of their action: consequently there is, in the aspect of the country, little to attract".

Javasche Courant, May 9, 1857 [in Adams 1912, p287]:

${ }^{*}$ According to Sapper [1917, p198], Daubeny was thinking of Fire $\mathrm{Mt}$, near Wetar. This inference, perhaps correct, seems to be based on the juxtaposition of two sentences.
The 26th or 27th of December, 1856, the mountain Iloen Bano in the western part of Timor erupted causing the death of two persons struck by stones which the volcano threw out. The account from which we are borrowing these details is all the more remarkable since it is the first notice of eruption of a volcano in Timor, or at least in the western part of the island.

Perrey [1858a]:

There was also, in the island of Timor, a mountain so high that its flaming summit was said to be visible three hundred miles at sea. In the year 1638 when its foundations were shattered by a terrible earthquake, together with the island, it was absorbed, leaving only a great lake in its place, as the annals of the Society of Jesus record [in Adams 1912, p287. Perrey, writing in Latin, cites Ittig as his source].

Scrope [1862, p463]:

The great peak of Timor once served, like Stromboli, as a lighthouse to mariners, being, from its vast height, visible at a distance of 300 miles. In 1638 a prodigious eruption blew off the greater part of the cone and replaced it by a large lake. It will be remarked that this is an event of frequent occurrence among the powerful volcanos of this quarter of the globe. $\left(1^{\text {st }}\right.$ edition $)^{\dagger}$

Zurcher and Margollé [2012, p133-134]:

In 1638, the colossal cone, called the Peak, in the Isle of Timor, disappeared entirely, and was replaced by an abyss now containing a lake. Until then this volcano, in continual activity, served as a lighthouse to mariners. $\ddagger$

Wallace [1869, p193]:

It differs, however, very remarkablytextcitepp[][p from all the other islands of the chain in not possessing any active volcanoes, with the one exception of Timor Peak near the centre of the island, which was formerly active, but was blown up during an eruption in 1638 and has since been quiescent. ${ }^{\S}$

\footnotetext{
${ }^{\dagger}$ Repeated in Scrope [1872] Über Vulkane. The wording differs a little in the various editions of Scrope's books. See also Adams [1912, p284].

$\ddagger_{\text {Reference is to translation of } 1868 \text { edition }}$

$\S$ Supporting comments are made on p17 and p210. Statements similar to that above are also made in subsequent editions.
} 
Hartwig [1871, p68]:

In the year 1638 a colossal cone called the Peak, in the Isle of Timor, one of the Moluccas, was entirely destroyed by a paroxysmal explosion. The whole mountain, which was before this continually active, and so high that its light was visible, it is said, three hundred miles off, was blown up and replaced by a concavity now containing a lake.*

Ponton [1872, p231]:

In Timor, the most easterly of these islands, there was once a mountain named the Peak, which used to be a volcano in constant activity, like Stromboli. It served as a lighthouse to mariners in those seas, being visible at a distance of 300 miles. During a great eruption in 1637 , however, the mountain disappeared bodily, leaving a lake in its place.

Wallace [1879, p429]:

It is generally considered that there are no volcanoes in Timor, and none were known to Mr Crawfurd when he compiled his valuable Dictionary. Mr. Scrope, however, in his work on volcanoes, speaks of Timor Peak as a mountain of great height, continually active before the year 1638, when it was blown up during an eruption, and replaced by a craterformed lake. Previous to this eruption the mountain was said to be visible 300 miles off, and was therefore probably the loftiest in the archipelago. Gunong Allas, about the middle of the south coast, is marked on the latest Dutch maps as being 11,500 feet high ${ }^{\dagger}$.

\section{Balfour [1885]:}

[Timor] has only one active Volcano, Timor Peak, near the centre of the island, which was blown up during an eruption in 1638, and has since been quiescent.

Symons et al. [1888, p385]:

In the List of principal ascertained volcanic eruptions from 1500 to 1886 , one item says simply "Timor 1637-38". There is no entry in the adjacent "List of unusual atmospheric phenomena, such as blue suns, dry fogs, and red twilights, and general remarks."

Bonney [1899, p230]:

\footnotetext{
${ }^{*}$ Repeated verbatim in $1887, \mathrm{p} 86-87$.

${ }^{\dagger}$ The above is repeated with minor differences in earlier editions.
}

The Javan line is continued from Soumbava by Sangeang, another Stromboli, through the Flores Islands to Timor, in which the existence of volcanoes has been doubted; there must, however, be a very few, for one in the western part of the island is said to have been in eruption in 1856 and in the following year; there are also some mud volcanoes, but nothing calling for special attention.

Wilson [1906]:

In 1638, the summit of the peak of Timor, which might be seen like a light-house from a distance of 270 miles, exploded, and blew up into the air, and the water collecting, formed a lake in the enormous void caused by the explosion.

Mercalli [1907, p313]:

Il vulcano dell'isola Timor fece una grande eruzione esplosiva nel 1638: altra violentissima eruziona esplosiva avenne al vulcano Floen-Bano, nella parta occidentale di Timor, il 26 dicembre 1856; infine una terza eruzione ebbe luogo al vulcano di Bibiluto nel maggio 1857 (Perrey).

[The volcano of the island of Timor made a grand explosive eruption in 1638, another violent explosive eruption occurred at the volcano Floen-Bano in the Western part of Timor the 26th of December, 1856; finally a third eruption took place in the Volcano Bibuluto in May 1857 (Perrey) $)^{\ddagger}$ - translation in Adams [1912, p285]].

Mercalli also quotes Scrope and notes further (p313):

Nel 1856, due persone vennero uccise dalle pietre che lanciava il volcano di Timor. La eruzione del 1857 venne accompagnata da terremoti fortissimi e da sprofondamenti dell suolo che fecero perire 36 persone (Perrey). Probablimenta tutte quests eruzioni sono da riferirsi a uno stesso volcano che porta diversi nomi. 
[In 1856 two people were killed by stones hurled out by the volcanos of Timor. The eruption of 1857 was accompanied by a strong earthquake and a fissuring of the ground which caused the death of 36 people (Perrey $)^{*}$. Probably all these eruptions should be referred to one volcano which bears different names. - translation in Adams [1912, p285]].

Schneider [1911, p241]:

Schneider's catalogue of volcanoes gives Floen-Bano as the name of the volcano in Timor, its longitude and latitude are stated as $126^{\circ} 30^{\prime} \mathrm{E}, 8^{\circ} 50^{\prime} \mathrm{S}$ and its location is given on a map (p190) as being in the eastern part of the island even though Mercalli had stated that Floen Bano is in the western part. The dates of the eruption of this volcano are given as 1638? 1856 and 1857 . The height of the volcano is given as $2400 \mathrm{~m}$ [see also Adams 1912, p286].

Adams [1912]:

Adams' paper, entitled "Timor Island; its supposed volcano and its probable tectonic relations" was the first to argue that there was no volcano on Timor $^{\dagger}$. He cites Scrope's book (a different edition to the one cited above $)^{\ddagger}$ and the quotations noted above from Bonney [1899], Mercalli [1907], and Schneider [1911]. Adams traces the source of the error concerning a 1638 eruption to Ittig [1671]. He traces information concerning the supposed 1856 and 1857 eruptions to Perrey [1858a; 1858b] whose original source for the 1856 account seems to have been the May 9, 1857 Javasche Courant.

Adams [1912, p286-287] believes that the 1856 account stems from the misinterpretation of earthquake phenomena that are then attributed to a volcanic eruption. He also notes that the mountain is called Iloen Bano and not Floen Bano as written by Mercalli and those who followed him. He also believes that Perrey was misled by assuming that the incidental mention of "volcanoes" in a non-technical report by the

\footnotetext{
*, p286 points out that this event occurred on Pulo Camby, a small island north of Timor. However, Wichmann [1918, p173-174] reports an earthquake around 10.30am on May 13, 1857 felt severely in Dili (the centre of government in Portuguese Timor) which also led to an eruption of the mud volcano at Bibiluto and to a tsunami. Later on the same morning on Pulu Kambing " 23 men, 13 women and an indeterminate amount of children departed this life". Cambing or Kambing are synonyms for the island of Artauro, a few $\mathrm{km}$ north of Dili.

${ }^{\dagger}$ However, St. John [1853, p20] noted, regarding Timor: "No volcanoes are found, and no traces of their action". See also, Earl [1852].

‡Adams [1912, p284] cites Scrope: "Such a catastrophe destroyed in the year 1638 a colossal cone, called the Peak, in the Isle of Timor, one of the Moluccas. The whole mountain, which was before this continually active and so high that its light was visible, it is said, three hundred miles off, was blown up and replaced by a concavity now containing a lake". Adams does not cite a year or other details for the reference to Scrope's book though we know that many editions appeared.
}

Portuguese governor of Timor describing earthquakes was sufficient proof of the existence of volcanic activity. He further notes that the 36 people reported killed in 1857 were on Pulo-Cambay [Pulau Kambing?] a small island to the north of Timor ${ }^{\S}$. Adams surmises that Perrey overlooked the fact that "Pulo" means "island". He describes a visit to a mud volcano near Viqueque $\left[8^{\circ} 52^{\prime} \mathrm{S}, 126^{\circ} 22^{\prime} \mathrm{E}\right]$ and believes that this is the volcano referred to by Perrey.

The Royal Geographical Society [1913, p385-386]:

Prof. George I Adams ... has come to the conclusion that Timor must be definitely struck off the list of volcanic islands (Philippine Journal of Science, vol. 7, Sect. A, No. 4, 1912). The current misconception seems to have been due principally to a statement in Scrope's well-known work on volcanoes to the effect that in 1638 a colossal cone in Timor was entirely destroyed by a volcanic catastrophe. This has been repeated by others, who have also referred to supposed eruptions of later date. The only basis for the idea seems to be the existence of a so-called "mud-volcano", which Prof. Adams visited. In his view its activity, with other supposed manifestations of volcanic force, has been a result of earthquake shocks. The original source of Scrope's statement appears to be Iltig's [sic] "De Montium Incendiis" (Leipzig, 1671), the Jesuit annals being there given as the authority; and it may be suggested that there was here a confusion between Timor and some other island of the archipelago. Prof. Adams makes no reference to Kotó's memoir on the geologic structure of the Malay Archipelago (Journ. Tokyo Coll. Sci., vol. 11, part 2)[1899], in which the same conclusion as to the non-volcanic character of Timor is arrived at.

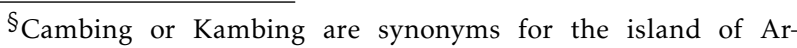
tauro, a few $\mathrm{km}$ north of Dili, the capital of East Timor [Boxer 1947; Kuenen 1937]. Alternatively, this could also be a reference to Pulau Komba, also known as Pulu Komba and Batu Tara some $50 \mathrm{~km}$ north of Lomblen. However, the only known eruption of this island, a small eruption, was from 1847 to August 1852. No fatalities are recorded in the Smithsonian catalogue (http://volcano.si.edu/volcano.cfm?vn=264260).
} 
Worcester [1914-1915, p127]:

Professor George S. Adams recently made a visit to the island of Timor, Malay Archipelago, and from observations he states that the volcanic character of the island (i.e. as far as active volcanoes are concerned), has been misconcepted. He alludes to the eruption, mentioned by Scrope in his work on Volcanoes, of 1638 , whom he says seems to have obtained this information from Iltigs [sic.] "De Montium Incendis" (Leipzig, 1671) which has probably been confounded from an eruption on a neighbouring island. Furthermore admitting the existence of a "mud volcano", which Prof. Adams visited the traveller comes to the conclusion that in the linear Volcanic belt, which extends through the east Idian [sic.] Islands, the island of Timor should be dropped out. This appears to be a sweeping statement, as the writer of this review is cognisant of the fact that there were eruptions from Timor as recently as 1856 and 1857 . Therefore a more satisfactory explanation would be required to "fully" substantiate the statement made by Prof. Adams.

Sapper [1917, p198]:

Fur die ausserhalb der eigentlichen Vulkanzone der kleinen Sunda-Inseln liegende Insel Timor gibt es mehrere Ausbruchnachrichten in de Literatur:

1638 [Here Sapper quotes the French source, de Montbéliard [1761]]

1856, [no month given] 26./27., Ausbruch des Iloen-Bano in West-Timor. Zwei Menschen durch Steine gettet.

1857, Mai, Ausbruch des Bibiluto. Perrey spricht nach offiziellen portugiesischen Berichten von zaheeichen Beben seit dem 15. Mai d. J. und einer starken Senkung, wodurch das Dorf Macdadi mit 36 Personen verschwand; auch ein teill van Rainha de Viqueque wurde zerstrt.

Da nun aber G.S. Adams die Ansicht vertritt, dass es echte Vulkane auf Timor nicht gibt, so wandte ich mich um Auskunft an den besten Kenner dieser Insel, meinen verehrten Freund G.A.F. Molengroff, der mir bestätigte, dass auf der Insel Keine Vulkane vorkommen, sundern nur Schlamm-vulkane, die ebenso wie die von Rotti und Saman "oft heftige Eruptionen haben und nebst Gas viel Schlamm und Gesteinsstcke ausschleudern". Auf solche Ausbruche sind jedenfalls die Nachtrichen von 1856 zurücksuführen, die von 1857 auf Bebenwirkungen, während bei der Nachtricht von 1638 eine Verwechslung vorliegt, wie schon Daubeny und neuerdings Adams vermutete. Daubeny (der allerdings 1637 schrieb) dachte an den Goenoeng Api bei Wetar. *

[1638. The peak of Timor island is so high, that one can see it from a distance of 300 miles the flames which it vomits out; almost all of the island was engulfed leaving in its place a great lake.

1856, 26/27 Eruption of the Iloen-Bano in west Timor. Two were killed by stones.

1857, May Eruption of Bibiluto. Perrey spoke from official Portuguese reports of the numerous shocks from the $15^{\text {th }}$ May of this year and a strong sinking whereby the villages of Macdadi with 36 people disappeared; also a part of the Rainha de Viqueque was destroyed.

G. S. [sic] Adams has now put forward another point of view, that there are no true volcanoes in Timor, so I turned to the person who had the best knowledge of the island, my dear friend G A F Molengroff, who stated, that no volcano occurs in the island of Timor, but only mud volcanoes, which however according to Rotti and Saman, "often have considerable eruptions and besides gas hurl forth much mud and pieces of rock". Of such eruptions are all reports of 1856 referred to, on the effect of this shock, during by the news of 1638 a confusion is put forward; as already Daubeny and more recently Adams surmised. Daubeny (who certainly writing of 1637) thought of Fire Mt. near Wetar (Gunung Api)].

Wichmann [1918, p31]:

(no date). Timor. The fear of the mountain and the other on the Island, named Picus, elevation so great that it was visible, and fiery in this case, to the top from 300 miles in the sea; the year 1638 an earthquake shook the foundations together with the island was swallowed up by a horrible thing, that had left behind nothing but a huge lake. Thus reference Annals Soc. Jesus 6)

Despite many-fold attempts it has not been possible to procure for myself the volumes of Litterae annuae taken into account, in order to understand the original relation. I can thus only repeat 7) that the record sounds very improbable, as there is no volcano known on Timor. Despite the exaggeration 8) it is still possible that this is a case of a mix-up. [All these footnotes refer to: Joh. Sigmund Wurffbain. Vierzehn Jährige Ost-Indianische Krieg-

\footnotetext{
${ }^{*}$ Sapper [1927, p330] is quite different to the above.
} 
und Ober-Kaufmanns-Dienste. StulzbachNürnberg 1686, p. 93-97.]

HMSO [1920, p2]:

It is not now believed that there are any volcanoes, but there are numerous mud geysers, perhaps the sign of former volcanic activity.

Lamb [1970, p502]:

1637-8 Timor. $9-10^{\circ} \mathrm{S} 124-7^{\circ} \mathrm{E}$. No estimate of the Dust Veil Index are given. Royal Society Krakatoa Volume 1888 "List of principal ascertained volcanic eruptions from 1500 to $1886 "$ is given as the source.

Lamb [1985, p9]:

1637. A reprint and update of Lamb [1970]. No further details are provided, but the date is now given as 1637 .

\section{Flexner and Flexner [2008, p77]:}

1638: Indonesian Volcano Explodes. Located on the island of Timor in modern-day Indonesia, the 10,500 foot volcano peak blew itself apart in a cataclysmic eruption, killing hundreds of people in the area"

GluedIdeas.com [n.d.]:

Repeated verbatim from Balfour [1885, p1033].

Timor, in violent eruption 1638, and a lake formed and peak disappeared.

\section{B Appendix 2}

My personal views of Kircher's story are complex. I am intrigued by the possibility that such an eruption may have occurred. While I am sure there are no volcanoes on Timor I find it hard to conclude that his account is entirely fanciful. Kircher's story could refer to the 1638 eruption of Raung (east Java), to one or more eruptions of Gunungapi Wetar (about $200 \mathrm{~km}$ north of Timor in the Banda Sea), Banda Api, or even Batu Tara on Komba Island, about $50 \mathrm{~km}$ north of Lembata (Figure 1). All three of these volcanoes are on early European sea routes to the Spice Islands [Pires 1944, p204]. While none of these island volcanoes have eruptions in the relevant timeframes recorded in the Smithsonian catalogue there are eruptions recorded in the accounts of early navigators in the area that need to be sorted out. Other possibilities include the 1538 eruption of Gamalama (on Ternate), or to another eruption in Indonesia or even further afield which has so far escaped our notice. In each case some or other details of Kircher's account seem to be at odds with eruption characteristics we might expect, though this need not necessarily imply that the story is fanciful.

Could the account instead refer to the subsidence of an area between Lembata and Pantar for which Barnes [1982] records a patchy oral history and which Vatter [1932] thought occurred mid- or late- $17^{\text {th }}$ century?

In 1888 , about $2500 \mathrm{~km}$ to the east of Timor, Ritter Island in the Bismarck Sea to the north of mainland Papua New Guinea collapsed producing a small eruption, a large tsunami, and leaving just a sliver of the original island remaining above sea level [Johnson 1987; Micallef et al. 2017; Silver et al. 2009; Watt et al. 2019]. Does this type of event sound more like Kircher's eruption of Timor?

Even more remarkably, $165 \mathrm{~km}$ west north west of Ritter Island, Mary Mennis [1981; 2005] has collected dozens of oral histories about a volcano called Yomba that erupted, created a large tsunami, and entirely disappeared beneath the waves a generation or two before the VEI 6 eruption of nearby Long Island (fairly securely dated to 1651-1671 C.E. - Blong et al. [2018]). The location of Yomba has never been accurately determined but it is generally believed to be at Hankow Reef $\left(4.88^{\circ} \mathrm{S}, 146.72^{\circ} \mathrm{E}\right)$ and, somewhat surprisingly, Yomba has been assigned a volcano number in the GVP catalogue (http://volcano.si.edu/volcano.cfm?vn=251041).

Could Kircher's eruption be like the eruption of Yomba? Could Yomba be Kircher's eruption, even though it is about $2300 \mathrm{~km}$ east of Timor? That is fanciful-unless we can find accounts of unknown (European?) navigators that not only ventured along the north coast of mainland Papua New Guinea between the voyages of Schouten and Le Maire in 1616 and Abel Tasman in 1642 but also corresponded (directly or indirectly) with Jesuits in Rome.

Our best chance of finding out more about Kircher's 1638 eruption of Timor probably lies in the Jesuit archives. 